\title{
Mangroves Living at the Edges: A Social Survey Based on Environmental Issue
}

\author{
A. Saleem Khan* and M. Sheik Ali** \\ Department of Biotechnology, The New College, Peters Road, Royapettah, \\ Chennai 600 014, Tamil Nadu, India \\ E-mail:*<saleemkhan83@gmail.com>,**<sheikvermi@gmail.com>
}

KEYWORDS Mangroves. Tsunami. Disaster mitigation. Awareness

\begin{abstract}
Mangroves form a unique ecosystem in a coastal environment that is in constant flux and forms productive biomes. They thrive in a salty environment like coastal regions and estuaries and aid towards disaster management by facing the onslaught of giant waves such as Tsunami. It is an important asset from an ecological standpoint. In recent years, Mangrove communities have been uprooted and destroyed due to anthropogenic activity. Realizing the importance of mangroves, a community based awareness survey was made and the importance of mangroves and its possible role in disaster mitigation are emphasized. Survey reveals joint efforts should be taken by both the government and the local community to conserve and grow mangroves to save mankind from disaster.
\end{abstract}

\section{INTRODUCTION}

The mangrove forests are one among the most productive ecosystems on this planet. They serve as custodians of their juvenile stock and form most valuable biomes (Odum 1971). Mangroves have very specialized adaptations that enable them to live in salty environments (Alka Shiva 2006). Naturally, resilient mangrove forests have withstood severe storms and changing tides for many millennia. This unexplored bounty was revealed only after the Tsunami disaster. The only nature's gift which stood bravely against tsunami other than the humanitarian services are the mangroves of the coastal regions (Khan and Ali 2007). Areas with dense mangroves suffered fewer human casualties and less damage to properties compared to areas without mangroves. But, today mangroves are destroyed mainly by man-made activities in different forms, which pose serious threat to the ecosystem around the map and silently become one of the reasons for Global warming and climate change. This is due to population growth and unsustainable economic development including deliberate land reclamation for urban and industrial development. With

Address for Correspondence:

A. Saleem Khan

Department of Biotechnology, The New College,

Peters Road, Royapettah, Chennai 600 014,

Tamil Nadu, India

Telephone: +919840588068

E-mail: saleemkhan83@gmail.com continuing degradation and destruction of mangroves, there is a critical need to understand them better (Kathiresan 2002) and now it is a need of the hour to concentrate and protect mangroves for generations.

\section{MATERIALSANDMETHODS}

Realizing the importance of mangroves, a community based awareness survey was conducted at Urrur kuppam, Adyar estuary, Adyar, Chennai, Tamil Nadu, India, which is the located mangrove region of Chennai zone. A survey was taken among 125 individuals; age group of 20 and above and the results were analysed. The questionnaire (see appendix) was prepared in Tamil (Native language of the locality) and also in English for the convenience of the people who live in that locality.

\section{RESULTS AND DISCUSSION}

The survey of social perspectives from the average literate group of population were revealed data concerning the social awareness and understanding of the mangrove ecosystem.

Though the survey was done at a location close to the existence of the mangrove trees, only $68 \%$ (Question 1) of the surveyed populations were aware of mangroves, of which 73\% (Question 2 ) were aware that they were useful tools of nature in protecting against giant waves such as Tsunami, while 27\% (Question 2) felt they were 
Table 1: Survey report

\begin{tabular}{|c|c|}
\hline Questions & $\begin{array}{l}\text { Percentage (\%) of } \\
\text { the respondents }\end{array}$ \\
\hline $\begin{array}{l}\text { 1. Are you aware of } \\
\text { Mangrove Trees? }\end{array}$ & $\begin{array}{l}68 \% \text { Yes } \\
32 \% \text { No }\end{array}$ \\
\hline $\begin{array}{l}\text { 2. If yes, briefly explain } \\
\text { what they are? }\end{array}$ & $\begin{array}{l}73 \% \text { Protects from } \\
\text { TSUNAMI } \\
27 \% \text { Increases } \\
\text { Fisheries }\end{array}$ \\
\hline $\begin{array}{l}\text { 3. Is growing Mangrove } \\
\text { trees important? }\end{array}$ & \\
\hline $\begin{array}{l}\text { 4. Rate the significance of } \\
\text { Mangrove trees }\end{array}$ & $\begin{array}{l}35 \% \text { Protects } \\
\text { from TSUNAMI } \\
24 \% \text { Increases } \\
\text { Fisheries } \\
21 \% \text { Soil Erosion } \\
20 \% \text { Ecological } \\
\text { Balance }\end{array}$ \\
\hline $\begin{array}{l}5 \text { The numbers of Mangrove } \\
\text { trees in coastal } \\
\text { areas are decreasing? }\end{array}$ & $\begin{array}{l}50 \% \text { Yes } \\
50 \% \text { No comments }\end{array}$ \\
\hline $\begin{array}{l}\text { 6. If yes, list out the reasons } \\
\text { for this. }\end{array}$ & $\begin{array}{l}50 \% \text { Pollution } \\
27 \% \text { No Proper Care } \\
23 \% \text { No Comments }\end{array}$ \\
\hline $\begin{array}{l}\text { 7. The phenomenon of } \\
\text { decreasing mangrove } \\
\text { trees affects the People } \\
\text { living in surrounding } \\
\text { regions? }\end{array}$ & $\begin{array}{l}65 \% \text { Yes } \\
35 \% \text { No }\end{array}$ \\
\hline $\begin{array}{l}\text { 8. Do you think this } \\
\text { situation can be saved? }\end{array}$ & $\begin{array}{l}57 \% \text { Yes } \\
43 \% \text { No }\end{array}$ \\
\hline 9. If yes, what are the ways? & $\begin{array}{l}69 \% \text { Awareness } \\
31 \% \text { In charge of } \\
\text { Local Panchayat }\end{array}$ \\
\hline $\begin{array}{l}\text { 10. Is this degradation } \\
\text { due to environmental } \\
\text { stress e.g. Industrial wastes, } \\
\text { Increasing Human } \\
\text { population? }\end{array}$ & $\begin{array}{l}73 \% \text { Yes } \\
27 \% \text { No }\end{array}$ \\
\hline $\begin{array}{l}11 \text { What according to you are } \\
\text { the measures that can be } \\
\text { taken in avoiding the } \\
\text { Destruction of Mangroves? }\end{array}$ & $\begin{array}{l}69 \% \text { Awareness } \\
31 \% \text { In charge of } \\
\text { Local Panchayat }\end{array}$ \\
\hline $\begin{array}{l}\text { 12. Who do you think can } \\
\text { reclaim Mangroves } \\
\text { effectively? }\end{array}$ & $\begin{array}{l}47 \% \text { Government } \\
33 \% \text { NGO } \\
20 \% \text { Resident } \\
\text { of the Area }\end{array}$ \\
\hline
\end{tabular}

useful for fisheries. In spite of knowing its importance only 64\% (Question 3) of the people acknowledged that growing mangrove trees is important.

On given an option with respect to significance of mangrove trees in a given ecosystem especially the coastal area it was indeed heartening to note that though 35\% (Question 4) felt it protected against Tsunami and 24\% (Question 4) facilitated fishery, 21\% (Question 4) of the people from the fishing community were also aware that it prevented soil erosion and $20 \%$ (Question 4) it was important for ecological balance. In spite of knowing this significance only 50\% (Question 5) of the population acknowledged that the density of mangrove was decreasing while the other 50\% (Question 5) preferred not to comment. Many attributed the cause for the depletion to be pollution or improper care by concerned stakeholders (Question 6), though being aware that the depletion in density would definitely affect the livelihood of people in those areas (Question 7).

Only 57\% (Question 8) of people are optimistic that the situation can be saved and they feel this could be achieved by creating awareness by the local Panchayat taking charge of this situation (Questions 9 and 11).

In conclusion, the survey reveals that the degradation of mangroves is due to environmental stress (Question10) and that any remedy could be achieved only by creating awareness. Though this need has been affirmed, ironically only $20 \%$ (Question 12) of the residents feel that they may have a role to play in reclaiming mangroves. $47 \%$ (Question 12) however feel that it is the government responsibility while 33\% (Question 12) feel that NGO would be able to reclaim effectively.

This survey was essential, as any ecological remediation to be carried out requires both awareness and participation of all stakeholders of that region. This survey along with its scientific findings would definitely serve as a note that would provide baseline data for the remediation or rehabilitation of the mangroves in Urrurkuppam, Adyar estuary, Adyar, Chennai, Tamil Nadu, India in particular and mangroves in general.

\section{CONCLUSION}

Besides being a wonderful place to explore, mangroves are also important from an ecological standpoint. They form a unique ecosystem in the environment and play an important role in governing the coastal ecosystem. In spite of its great importance, degradation of mangroves is an alarming issue. They form the most threatened habitats in the world, disappearing at an accelerating rate with little public notice (Khan 2007). Humans definitely have an enormous influence on how well mangroves survive. Awareness to local people has to be created especially on the importance of mangroves and their management. The community based survey reveals that the conservation and management progamme of mangroves should concentrate on 
mangrove management and its possible role in disaster mitigation. Very importantly opinion from local community is essential in implementing the projects related to mangrove ecosystems and local communities must be involved during the mangrove tree plantation. Government and other agencies of environmental concern should implement effective environmental policies to conserve mangroves and save mankind.

\section{ACKNOWELDGEMENT}

The authors are grateful to TNSCST - Tamil Nadu State Council for Science and Technology for funding the project on behalf of the Department of Science and Technology (DST) of the Government of India, New Delhi, India. (Project code: ES-15, 2006-2007). We are indeed grateful to Ms. Nirmala, Lecturer in Psychology, Kannika
Paramesvari College, Chennai, Tamil Nadu, India for assistance in preparing the survey. The authors are also very much thankful to The New College, Chennai for their constant support and encouragement.

\section{REFERENCES}

Alka Shiva MS 2006. Spectrum - Mangrove forests to combat Tsunami disaster Science Reporter, 43(5): 16.

Kathiresan K 2002. Why mangroves are degrading? Current Sciences, 83: 1246-1254.

Khan AS 2007. Bacterial survey of mangrove forest-A life saving vegetation. Proceedings of Student Projects Scheme Seminar, Tamil Nadu State Council for Science and Technology, pp. 306-307.

Khan AS, Ali MS 2007. Mangroves - an ecosystem in peril. Journal of Current Sciences, 10(1): 419.

Odum EP 1971. Fundamentals of Ecology. Philadelphia: W.B. Saunders Company and Toppan Company, pp. $574-575$. 